UDC 81'243:371.315

DOI https://doi.org/10.24919/2663-6042.16.2021.13

\title{
GAMIFICATION AS A COMPETITIVE BENEFIT IN TEACHING A FOREIGN LANGUAGE
}

\author{
Kuprikova S. V., Savkovska H. Yu. \\ Rauf Abliazov East European University
}

The article examines epy specifics of using gamification as one of the most effective tools in the higher education system, which diversifies and increases the effectiveness of foreign language learning. The article aimed to identify gamification as a competitive benefit in teaching a foreign language. The object of the study is the motivation of students to learn a foreign language as a prerequisite for achieving a high level of knowledge. The subject of the study is the use of gamification tools as a means for increasing the motivation of students to study foreign languages.

The authors of the article consider the place of gamification in the field of education in connection with the development of digital technologies, distance and blended learning; involvement in the educational environment of the "generation of computer games". The connection of the origin of the term "gamification" with the spread of information technology and the introduction of game techniques in the learning process is determined in the paper. The differences between gamification and other types of learning and game activities based on learning are analyzed.

The authors emphasize that gamification element in the process of learning a foreign language increases motivation significantly. The evidence from this study suggests gamification is a relatively new technique that has been insufficiently studied but has a wide educational potential. Therefore, it can be used in various spheres of human life, but in the last viewed as one of the most promising innovative approaches in conducting lessons at university.

The main elements of the game are studied and their influence on the level of students 'encouragement and incentive in foreign language classes is revealed. The problems that can be faced by a teacher who introduces types of gamification into the educational process are highlighted. Examples of the use of gamification in teaching students a foreign language that help to overcome a language barrier are given. It is proved that the target orientation of gamification participants is designed not only to achieve results, but to acquire new skills and abilities. It is substantiated that involvement in joint work increases students 'motivation and promotes the development of communicative competence and improvement the quality of educational process.

Key words: gamification, blended learning, game element, motivation, learning efficiency, communicative competence, language barrier, badges, leaderboards, charts of achievements, lexical quests, educational game strategy, competition.

Купрікова С. В., Савковська Г. Ю. Гейміфікація як конкурентна перевага у навчанні іноземної мови. У статті розглянуто особливості використання гейміфікації як одного з найефективніших інструментів у системі вищої освіти, щзо урізноманітнює та підвищує ефективність вивчення іноземної мови. Мета дослідження полягає в тому, щуоб виявити гейміфікаџію як конкурентну перевагу у навчанні іноземної мови. Об'єктом дослідження є мотивація студентів до вивчення іноземної мови як передумова досягнення високого рівня знань; предметом дослідження - використання інструментів гейміфікації як засобу підвищення мотивачії студентів до вивчення іноземної мови.

Окреслено місие гейміфікаиії у сфері освіти у зв'язку з розвитком иңифрових технологій, дистанційного та змішаного навчання; залучення до освітнього середовища “покоління комп 'ютерних ігор”. У роботі визначено зв'язок походження терміна «гейміфікація» з поширенням інформаційних технологій та впровадженням ігрових прийомів у процес навчання. Проаналізовано відмінності між гейміфікацією й іншими видами навчання та ігрової діяльності на основі навчання. Наголошено, щзо елементи гейміфікації в процесі вивчення іноземної мови значно підвищують мотивацію.

Дані запропонованої розвідки засвідчують, щзо гейміфікація є відносно новою технікою і має недостатні знання, але водночас широкий освітній потенціал. Тому він може використовуватися в різних сферах життя людини, але останніми десятиліттями його розглядають як один з найперспективніших інноваційних підходів до проведення занять у виші.

Досліджено основні елементи гри та розкрито їхній вплив на рівень заохочення й стимулювання студентів при вивченні іноземної мови. Висвітлено проблеми, з якими може зіткнутися педагог, який впроваджує у навчальний прочес види гейміфікачії. Наведено приклади використання гейміфікації в навчанні студентів іноземної мови для подолання мовного бар'єру. Доведено доиільність ијільової орієнтації учасників гейміфрікації не лише на досягнення результату, а й на набуття нових умінь та навичок. Обгрунтовано, що залучення до спільної роботи та підвищення мотивації студентів сприяє розвитку комунікативної компетентності та підвищенню якості навчального процесу.

Ключові слова: гейміфікачія, змімане навчання, ігровий елемент, мотивація, ефективність навчання, комунікативна компетентність, мовний бар'єр, значки, табличі лідерів, діаграми досягнень, лексичні квести, стратегія навчальної гри, змагання. 
Defining the problem and argumentation of the topicality of the consideration. Modern people live in a special interactive play space, so it is important to create a comfortable environment for them. The realities of the world reveal specific political and social trends. Moreover, the search for new and non-standard approaches increases the level of efficiency management in various educational systems. The purpose of teaching a foreign language at university is development of the student's personality through a system of knowledge about language, skills and abilities in various types of speech activity. Achieving this goal seems impossible without the formation of a communicative competence. So gamification as one of the latest technologies for organizing the educational process is very useful. Modern technology development, accelerating the pace of life necessitate the introduction of interesting, interactive teaching methods, as the modern education system is rapidly becoming obsolete and does not meet the requirements of the time.

One of the oldest problems in teaching a foreign language is the involvement of students in the educational process, which is associated with low motivation and lack of interest in the subject. The introduction of various educational technologies and methodological tools will not provide a full-fledged solution to this problem.

An incentive in teaching a foreign language at university is not often connected with game elements that create a competitive environment, generate curiosity and excitement and bring instant satisfaction from achieving a set goal and receiving a well-deserved reward. In this regard, in this work we will try to study and evaluate the possibilities of gamification for the acquisition of foreign language competence by the students. Gamification should be viewed as a tool to improve the efficiency of educational process in order to be competitive in the global market. Thus, the study of gamification as a competitive benefit in teaching foreign languages is relevant at the present stage of its development.

Analysis of recent research and publications. To understand the essence of gamification, we need to refer to its origin. Gamification in studying has been investigated by foreign and domestic scholars. Thomas Malone published his research "What Makes Things Fun to Learn? A Study of Intrinsically Motivating Computer Games" in 1980. Later, Woodrow Wilson International Center for Scholars, based in Washington DC, created the Serious Gaming Initiative to Study Applications principles of the game in matters of public policy. From this initiative gamification of education arose, which gradually turned into the area of interest. So using games to promote learning is not a new idea. The term "gamification" was first used in 2002. Nick Peeling used this term when designing the user interface $[5,3]$.

The linguistic researches emphasize the significant potential of interactive methods in the study of foreign languages; in particular, they underline their effectiveness for mastering arrays of foreign terminology language. For example, the researcher of modern trends in teaching foreign languages N. V. Zaitseva accents on new forms and methods usage $[1,30]$. Kevin Wehrbach and Dan Hunter consider that "entertainment is an extremely valuable tool for solving serious business problems related to marketing, efficiency, innovation, customer engagement, work with staff and stable development" [9]. The motivational component of gamification has become the subject of research by Yu-kai Chou [8]. Shapiro J. explored video games features in the educational process, the scientist is a supporter of the use of gaming teaching methods, but emphasizes that "it is necessary explain to students how and why the game is consistent with general learning context [7]. Thematic researches on gamification in the educational context continues due to the widespread use of adaptive learning systems based on games, the explosion of mobile educational programs and the rapid growth of the use of game strategies, which makes gamification one of the most important educational trends of the last decade.

Setting the goals and tasks of the article. Inclusion of elements of gamification in the process of learning a foreign language significantly increases motivation, which is achieved through the plot, design and interactivity of educational games. The purpose of the study is to explore the benefits of gamification as a factor of improving the quality in foreign language learning. The practical use of gamification in relation to the specific system of higher education is considered as one of the effective tools that increase the effectiveness and competitiveness of education.

The outline of the main research material. The concept of gamification in education is relatively new and actively developing at the present stage. It involves using the excitement and motivation characteristic of gaming to achieve educational goals. The idea of using gamification is rooted in the successful development of the gaming industry, both computer and desktop, social networking, marketing, and is based on decades of research in the field of psychology. Foreign researchers give different definitions of gamification. For example, the most influential gamification guru, American Gabe Zichermann has defined gamification as "the process of using game thinking and game dynamics to engage audiences and solve problems" $[10,15]$. Jo Kim believes that gamification is the use of gaming technology in order to make tasks more fun and cheerful. Karl Kapp gives the most detailed definition of gamification. In his opinion, it is the use of principles of game mechanics, aesthetics and thinking in order to engage learners in the educational process, increase motivation, activate learning and problem solving [4, 10]. We fully agree with foreign and domestic scholars that gamification contains four important components such as:

1) the concept of a game implies the presence of a goal that must be achieved, rules that determine possible ways to achieve a goal, a system for evaluating results that demonstrates progress in relation to the goal;

2) the concept of an element of a game helps to understand the difference between gamification and a real game and involves not creating a new game, but using only its individual elements, and in non-game situations;

3 ) the concept of technology or design define the approaches and techniques that are characteristic of the development of games and help to make them attractive to participants and to support this interest throughout the game; 
4) the concept of a non-game context determines the scope of this concept, when this formulation, firstly, implies that this area is wide enough, and secondly, it focuses on the difference between gamification and learning based on games (game-based learning), which involves the use of specially developed games in the educational process.

For example, O. O. Makarevych defines gamification as "the use of game mechanics typical of video games in software tools for non-game areas in order to attract users and consumers, increase their interest in solving applied problems, use of products, services" [2, 275]. Moreover, Andrzey Marczewski in his work "Gamification: a simple introduction" focuses attention on engagement, motivation, behavioral change and productivity $[5,3]$. Thus, the main idea of gamification is to influence participants' behavior and actions using a natural desire to play games.

Nowadays game concepts are increasingly used in areas other than the standard game environment. We can say that the main principle of each game is to achieve a certain goal. No matter what kind of goal is set (to win a prize, complete a task, and defeat a competitor or take the first place in the leaderboard), this is undoubtedly a mechanism including motivation, involvement, emotions and the certain behavioral. Elements of the gamified process today are: progress, levels, points, investments, achievements, teamwork, virtuality, incentive, bonuses, countdown, discovery, warning $[3,306]$.

The main goal of using gamification in education as a way to control knowledge is to apply in practice the latest educational technologies to attract students' attention to the subject and increase the level of motivation for learning foreign languages. Typical techniques and approaches in educational system stimulate students' interest, enthusiasm, and concentration enjoying not only the result, but also the process. An active participation in gamification process is the strongest stimulus for mastering a foreign language. In this situation, not a teacher, but the very condition of participation in the game with a certain stock of foreign words and expressions unobtrusively guides students to study foreign language vocabulary and grammar.

Thus, there are a lot of game elements and technologies at teacher's disposal which he can successfully modify in accordance with educational goals. Namely, points are awarded for completing certain tasks within the game and serve as a numerical expression of progress in relation to the goal. They help to determine the leaders of the game, indicate a situation in which a win or a reward is supposed, for example, a certain badge, a transition to another task or level. So scoring is a motivating factor for the majority of participants as it encourages and contributes to the pursuit of game success. A useful gamification feature is the introduction of game bonuses in educational situations and the receipt of some kind of reward for completed tasks, because the traditional assessment system no longer motivates students. Gamification is based on the triad of the main elements: points, showing the progress of passing through the game space; badges, which are more of a pleasant addition for both high scores and low scores; and boards of leaders which display the player's progress in the game space.

Badges are visual evidence of the success of the participants and are awarded upon reaching a certain number of points / levels. Badges play the role of a reward; they are symbols of the player's status and are designed to motivate participants to further achievements.

Leaderboards look like a list of players, ranked according to their achievements and allow game participants to compare their performance with those of other players. Leaderboards bring an element of competition to the game and, as a result, they can motivate participants for whom it is especially important to be no worse, and, if possible, better than others. However, the impact of leaderboards can be negative on some participants, if they decide that the gap between them and the leaders is too great, and no amount of effort will be able to close it. So in such a situation students' motivation can decline.

Other examples of game elements are progress indicators. Progress bars, which determine the position of the player in relation to the set goal, performance graphs showing the player's progress regarding his previous achievements, quests or tasks that participants perform during the game, the levels of the game, breaking it into stages, as a rule, with an increasing level of difficulty. However, in some cases the path to gamification may be associated with certain difficulties. Let's consider them in more details, and also outline some ways to overcome them.

First of all, the introduction of some elements of the game into the curriculum does not mean that the students' interest will arise automatically and the rise in motivation is guaranteed in this project. What motivates one person leaves another completely indifferent. Therefore, we need a deep understanding of psychological processes related to motivation; a preliminary analysis of the prevailing type of motivation in groups, and the development of tasks for encouragement. It is very useful at the preparation stage to discuss such a project with students, listen to their opinions and suggestions, and involve them in the development of assignments. Self-development of games in small groups under the guidance of a teacher is of great interest among students. This type of creative task encourages the search for additional information on the studied discipline, stimulates creativity and motivation, and allows enjoying both the process of creating a game and the results of studying. The result as a rule is highly appreciated not only by the teacher, but also by other students who become participants in the newly created game.

Another obstacle to the active introduction of gamification into educational process is the necessity to work with a large number of students. It requires sophisticated quantitative analysis and visual display of results, which involves the use or creation of appropriate software. A similar situation arises if the creators of an educational product with elements of gamification believe that it must necessarily include leaderboards, charts of achievements, and other technologies for visual presentation of information. One way to tackle this problem is to leverage existing gaming educational platforms such as Kahoot !. This platform allows educators to create 
tasks in the form of quizzes, for which the program awards points and determines leaders.

An important role in this stage is also played by the awareness of the fact that gamification implementation in teaching practice is not always associated with digital technologies, since the goal is not to create a fullfledged computer game, but rather, the reproduction of a game situation for the realization of the goals of the lesson. For this, in most cases, chalk and a board or paper and multi-colored markers are enough, and, of course, detailed rules of the game and the necessary game props: special cards with tasks, a dice, etc.

Engagement of gamification elements in the process of foreign language learning significantly increases motivation, which is achieved through the plot, design and interactivity of educational games. A widespread distribution of games, the development of the Internet and the need to create attractive educational practices led to the emergence of gamification as a new form of education and professional increase. Many educators notice the potential of gamification in complementing and expanding opportunities traditional teaching, but some researchers consider in this phenomenon an opportunity to change the entire educational paradigm, where the emphasis will be on social interactive learning rather than on teacher-supported learning and self-study.

On the surface of gamification is the idea of using a game approach to make teaching and learning more fun. But if you deal with this phenomenon seriously, you can find such invaluable learning opportunities as involvement in the learning process, high motivation, autonomy and semantic content. By gaining the necessary experience in games, safe boundaries are established within which phenomena can be investigated and practiced without a fear of making mistakes, since you can always press the restart button and become the champion in the next game. The game is the perfect learning environment with built-in resolution for a mistake that encourages you to think outside the box and develop self-control. Gamification is a way to influence learners. In e-education games can replace boring typical tasks, and with traditional training they can diversify an existing class format. The real value of gamification is that the game principle contributes to the creation of meaningful learning experience.

The goal of any game is to create a system in which players have an abstract task involving trials and difficulties in the course of its implementation. The game has certain rules, is highly interactive and evokes a positive emotional response. The tasks of the game are to earn points, bonuses, and promotion to the next level. It is hard to imagine gamificaton without a beautiful aesthetic appearance and high-quality graphics. Game thinking is perhaps the most important element of gamification, as it gives special meaning to simple actions, adding elements such as competition, collaboration, research, etc. Another factor of gamification is the involvement of participants, i.e. attracting their attention and engaging them in the educational game strategy.

Systematic study of a foreign language is the next step. During the game we practice correct pronunciation of words (phonetics), rules for composing sentences in the desired tense and voice (grammar), repeat and learn the meaning of new words (vocabulary). As we know, phonetics, vocabulary and grammar are the "three whales" in teaching a foreign language. Gamification as a tool for mastering a foreign language can promote the development of the game reflex, which, in turn, will improve student activity in the classroom. According to researches and experiments conducted in the classroom, it is easy to find solutions to improve work with students. One of the effective methods of learning a foreign language can be lexical quests with elements of gamification, when using badges, scores, participant ratings, levels, avatars or representations of characters in movies, as well as social elements and rewards. Games can be effectively used in innovative foreign language teaching at universities. Gamification allows achieving goals by giving people the opportunity to play and have fun. Learning is perceived as fun and entertaining process. There are various methodological techniques in teaching English. Let's consider the most popular ones among our students: The Hat, Taboo, Who Am I, the Wonders of the World, etc.

1. Game "The Hat". Before the start of the game, all participants are given blank sheets of paper with a request to write words on a given topic (words can be specific "book, laptop, vase, lamp" and abstract "love, friendship, happiness, business"). Then the sheets of paper are folded and put in a hat. The players take turns giving an explanation to the word that is indicated on the piece of paper. There is another version of the game, when a mouth is drawn next to the word, then the players can use words to explain. If next to the word there is a picture on which hands are depicted, participants use gestures or facial expressions. If next to the word a pencil is depicted, you need to draw a picture to explain the word. Every player can play for himself or can be in a team. The team will have to guess what the participant wants to convey to them. You can play for a while - who will guess more words at the allotted time. This game develops attention, imagination, erudition, forms a team spirit. It also allows to develop new, sometimes hidden abilities: drawing (when it turns out that the student is good at drawing), eloquence, quick wit, plasticity and dexterity (when it turns out that the student perfectly knows how to control his body and skillfully shows any situations, do not hesitate in front of an audience). Also "The Hat" develops listening, speaking, phonetics, vocabulary and grammar and helps to overcome the language barrier in communicative situations.

2. Game "Taboo". Each player takes a card on which a word is written and it must be explained without the use of taboo words (words that cannot be used). These forbidden words are usually the words that first come into head. For example, to explain the word "a tulip" you cannot use the words "flower, spring, love". The winner is the one who guessed the most words. It can be played with time limit, only one minute is given for an explanation. The game develops communication skills and promotes a rapid expansion of vocabulary.

3. Game "Who Am I". The names of celebrities or world famous scientists, artists, rulers are written down firstly. One player is given a sticker or leaflet with the name of a famous person, but so that this name is not visible to the selected player, but only to all other 
participants. The selected player asks 5 or more questions (the limit of questions is determined before starting games) and after receiving answers to the questions from other participants, the selected player must guess who he is.

4. Another example of the use of gamification is "The Wonders of the World". It is the development of a multilevel quest consisting of three sections (Wonders of the Ancient World, Wonders of the Modern World, Achievements of Science and Technology), each of which has two levels of difficulty. The first level involves testing the basic knowledge gained while studying these topics in a foreign language. Passing the second level of difficulty requires studying the recommended additional material. The winner is the player or team with the maximum number of points. Such tasks not only encourage students to work out the educational material as fully and in detail as possible, but try to expand their knowledge according to the proposed topics, self-searching for sources or using recommendations given by the teacher.

So, as you see, the process of modern gamification using the latest computer and mobile interactive technology has become an integral part in adult life. While using this fun and addictive game for an unobtrusive, non-traditional, but effective and entertaining teaching of a foreign language students both play and study in the lessons. The effect of competition increases the activity of students and labor productivity. The main goal of any game is to win. In order to win, you need $100 \%$ participation, and mobilization of all forces and knowledge. Also, during the game additional resources of students are revealed, their artistic, literary, musical, artistic or other potential depending on the task of the game.

Games promote emotional relaxation and overcoming a language barrier. Any game takes a person out of a serious, stressful state, which is unconsciously created when a person tries to master a foreign language. Even a professional translator can feel tense during important negotiations. Games relax and de-stress students. Everyone who practices yoga knows if a person is relaxed, he will show and achieve high results. Also it is better and easier to overcome the language barrier in a relaxed and psychologically calm condition. During the game, we create a communicative situation. A certain communicative situation may be changed. The goal of learning a foreign language is interchangeable - to explain a word, to be understood, to understand what they are trying to explain to you, to perform a necessary action and, finally, win. Creation of a favorable atmosphere in the classroom is very useful. The game promotes friendly support, mutual assistance, and team spirit, i.e. when everyone is involved in mutual process. Team building affects student's progress positively and creates a friendly atmosphere in the classroom while learning a foreign language.

Nowadays game concepts are increasingly used in areas other than the standard game environment. We can say that the main principle of each game is to achieve a certain goal. No matter what kind of goal is set (to win a prize, complete a task, and defeat a competitor or rank first in the leaderboard), this is undoubtedly a mechanism that includes motivation, involvement, emotions and a certain behavioral pattern. No wonder that game elements are used in non-game contexts, such as marketing, business, e-commerce, education, work environment, social media, etc.

Gamification in education offers many potential benefits, including the following aspects: 1) students feel "masters" in learning process; 2) a more relaxed atmosphere in regards to failure as students can just try again; 3) more enjoyment in the process of a study session; 4) learning becomes visible and fixable with the help of progress indicators; 5) learners can show intrinsic motivation to learn; 6) students can use different learning strategies with different avatars / characters; 7) students often feel more comfortable in play environment $[6,25-26]$.

It should be noted that there is a difference between game learning and gamification. Game learning offers education seekers who achieved educational goal through play activities. The essence of gamification is that it takes place in a non-game context, so it is used as such in a way that does not change existing learning practices, but instead focuses on making it more attractive and challenging for students.

In our technological world every teacher needs to expand and combine their methodological tools with the latest methodological findings to modernize the classical model of practical training. Game elements transfer to a non-game environment for teaching a foreign language can improve learning outcomes. Gamification in teaching implies the use of modern online games rules to motivate students and achieve real educational goals in educational subject course. With the transition of education to distance and blended learning, the needs of both teachers and graduates have changed, which requires the use of interactive forms and methods of teaching that enhance the effectiveness of learning in general, and a foreign language in particular.

Conclusions and directions for further research in this area. The strategy of gamification in education is relatively new and actively developing at the present stage. It involves using the excitement and motivation characteristic of gaming to achieve educational goals. Today gamification is a specific tool which helps to influence a modern student who is used to play computer games, and communicates in social networks. With the help of gamification it is possible to overcome some of the problems and contradictions that exist in teaching a foreign language such as insufficient motivation of students and their multilevel training. Gamification allows teachers to achieve the main goal, giving students opportunities and advantages not only to play and entertain but gain knowledge and communicative competence.

Gamification has become popular tactics to reward specific behaviors and improve motivation and participation in our digital age. New educational programs help teachers to find a balance between achieving their goals and meeting the growing needs of students. So gamification is considered to be a competitive benefit in teaching a foreign language both at distance learning and blended learning. It helps to involve teachers and students into the "generation of computer games" successfully. In our opinion, gamification is one of the most promising innovative approaches in conducting lessons 
at university; and namely participation in joint work increases students' motivation and promotes the development of communicative competence and improves the quality of educational process. We should note that this publication does not solve gamification issues fully, so further investigations are considered to be promising to analyze the features and criteria of gamification elements, and develop gamified control system to test in practice the effectiveness of gamication in teaching a foreign language.

\section{BIBLIOGRAPHY}

1. Зайцева Н. В. Інноваційні технології у викладанні іноземних мов. Інновації в професійній діяльності педагога : проблеми, теорія, практика : матеріали міжнар. наук.-практ. конф. 17-18 жовтня 2019 р. Одеса, 2019. С. 30-32.

2. Макаревич О. О. Гейміфікація як невід’ємний чинник підвищення ефективності елементів дистанційного навчання. Молодий учений. 2015. № 2 (17). C. 275-278. URL: http://molodyvcheny.in.ua/files/journal/2015/2/357.pdf.

3. Ткаченко О. Гейміфікація освіти : формальний і неформальний простір. Актуальні питання гуманітарних наук. 2015. Вип. 11. URL: http://drohobych.net/youngsc/AQGS/2015_11/Pedagogy/303-309.pdf.

4. Kapp K. M. The gamification of learning and instruction : game-based methods and strategies for training and education. John Wiley \& Sons, 2012. 336 p. URL: https://www.goodreads.com/book/show/13245515-the-gamification-of-learning-andinstruction.

5. Marczewski A. Gamification : a simple introduction, New York, 2013. 288 p.

6. Reiners T., Wood L. C. Gamification in education and business, New York : Springer, 2015. 697 p.

7. Shapiro J. Making Games: The Ultimate Project-Based Learning : KQED, 2014. URL: https://ww2.kqed.org/mindshift/ series/guide-to-games-and-learning.

8. Yu-kai Chou. Actionable gamification: Beyond points, badges, and leaderboards. Octalysis Media Fremont, CA, USA. 2015.

9. Werbach K., Dan Hunter. For the win: how game thinking can revolutionize your business. Philadelphia : University of Pennsylvania, Wharton Digital Press, 2012. 141 p. URL: https://ww2.kqed.org/mindshift/ series/guide-to-games-and-learning.

10. Zichermann G., Linder J. Game-based marketing: inspire customer loyalty through rewards, challenges, and contests. John Wiley \& Sons, 2010. 240 p.

\section{REFERENCES}

1. Zaitseva, N. V. (2019). Innovatsiini tekhnolohii u vykladanni inozemnykh mov [Innovative technologies in foreign language teaching]. Innovatsii $v$ profesiinii diialnosti pedahoha: problemy, teoriia, praktyka (Materialy mizhnar. nauk.prakt. konf.). Odesa, 30-32 [in Ukrainian].

2. Makarevych, O. O. (2015). Heimifikatsiia yak nevidiemnyi chynnyk pidvyshchennia efektyvnosti elementiv dystantsiinoho navchannia [Gamification as an integral factor of the distance learning effectiveness increase]. Molodyi uchenyi, 2 (17), 275-278. Retrieved from: http://molodyvcheny.in.ua/files/journal/2015/2/357.pdf [in Ukrainian].

3. Tkachenko, O. (2015). Heimifikatsiia osvity: formalnyi i neformalnyi prostir [Gamification of education: formal and informal spase]. Aktualni pytannia humanitarnykh nauk, 11. Retrieved from: http:// drohobych.net /youngsc/AQGS/2015_11/ Pedagogy/303-309.pdf [in Ukrainian].

4. Kapp, K. M. (2012). The gamification of learning and instruction: game-based methods and strategies for training and education. John Wiley \& Sons. Retrieved from: https://www.goodreads.com/book/show/13245515-the-gamification-oflearning-and-instruction.

5. Marczewski, A. (2013). Gamification: a simple introduction. New York [in English].

6. Reiners, T., L. C. Wood (2015). Gamification in education and business. New York: Springer.

7. Shapiro, J. (2014). Making Games: The Ultimate Project-Based Learning. KQED. Retrieved from: https://ww2.kqed. org/mindshift/ series/guide-to-games-and-learning.

8. Yu-kai, Chou (2015). Actionable gamification: Beyond points, badges, and leaderboards. Octalysis Media Fremont, CA, USA.

9. Werbach, K., Hunter, D. (2012). For the win: how game thinking can revolutionize your Philadelphia: University of Pennsylvania, Wharton Digital Press. Retrieved from: https://www.researchgate.net/publication/273946893_For_the_Win_ How Game Thinking can Revolutionize your Business.

10. Zichermann, G., Linder, J. (2010). Game-based marketing: inspire customer loyalty through rewards, challenges, and contests. John Wiley \& Sons. 